\title{
Is Consumer's Rooming Behavior Good or Bad for Retailers? - Focusing on Shopping Value of Global Consumers -
}

\author{
Gwijeong Park \\ Dept. of Business Administration, Gyeongsang National University \\ 501 Jinju-daero, Jinju, Gyeongsangnam-do, 52828, South Korea \\ 5590812@hanmail.net; id1031@gnu.ac.kr
}

\begin{abstract}
This study aims to investigate consumers' rooming behaviors, which are referred to showrooming, web-rooming, and morooming, and also to investigate whether rooming behavior is a factor that would reduce the competence of the retailers. In order to achieve the research purpose, the analytical methods were used, including exploratory and confirmatory factor analysis, correlation analysis, group mean analysis and path analysis. As a result, it was found that there is a difference in shopping value affected by consumers' nationality out of global consumers who have experiences of rooming behaviors. Also, there is a difference in the shopping value by groups; one with high familiarity to rooming behaviors and the other with low familiarity with rooming behaviors. In addition, the shopping value of consumers showed more favorable attitude under mediating effect of high familiarity, and it also showed positive influence on purchase intention. In conclusion, consumers' rooming behavior does not weaken corporate profitability, but rather, it activates transactions between consumers and companies, providing various benefits to consumers and enhancing company growth.

Rooming behavior is a natural phenomenon that can appear in the consumer purchasing decision making process, and it can be seen from this study that large amount of bi-directionality of purchase decision making through rooming behavior can help the company growth. The results of this study can provide useful suggestions to channel manager and practitioners in establishing penetration strategies for global consumer markets.
\end{abstract}

Keywords: shopping value, showrooming, web-rooming, morooming, rooming behavior

\section{Introduction}

Widespread usage of smart devices through the world, including PCs, mobile, tablets, and smart watches, has led to the diversification of distribution channels and the usage of these channels is referred to $\mathrm{O} 2 \mathrm{O}$, Omni, or multi-channels for e-shopping. The various distribution channels represent activation of cross-shopping behaviors of consumers. The spread distribution channels trigger complex purchasing decisions. As a result, this trend has caused consumer' behaviors such as 'showrooming,' 'web-rooming,' 'morooming' and so on. With common type of local distributors operating online agencies, these kinds of remarkable trends of online retailers adding offline arms have brought an attention to this ongoing revolution in the retail industry. This implicates merging online with offline channels into one single platform is the key issue in the retail industry. Accordingly, these trends eventually have caused several types of consumers purchase behaviors. 'Showrooming' is a newly coined term compounding the word 'showroom' with ' ing' which refers to a shopping behavior that a consumer who explores a product in an offline

Received (April 7, 2018), Review Result (June 2, 2018), Accepted (June 7, 2018) 
store and buys the product at an relatively inexpensive online store. On the other hand, 'Reverse-showrooming' refers to a shopping behavior of users who browse products through an online store and purchase products using offline stores. 'Morooming' refers to a shopping behavior of purchasing through the mobile after searching for products in the offline store which is similar to showrooming though. And 'Web-rooming' refers to a shopping behavior of who buys a product in the offline store after comparing the products through the websites by using devices such as tablet, and PC [2, 9, 18, 23, 24].

In the bases of previous studies, this study aims to define the 'rooming behavior' as a set of information search and purchase decision making process of consumers' using various smart devices(cross-shoppers, multi-channel shoppers and Omni channel shoppers) $[16,19,22]$. In other words, rooming behavior is understood as a concept integrating the actions of consumers such as showrooing, mooring, and reverseshowrooming and so on [19]. Meanwhile, multi-channel purchases tend to increase due to consumers' rooming behavior in the various spectrums. As smart devices have widely been introduced and common in daily life, consumers tend to spend more time in searching for product information and reviews needed for online shopping. Omni shopping has also become more common, which provides the most optimal benefits for consumers by crossing channels. However, on the other hand, consumers' free riding on cross-channel, which means customers' free channel switching behavior in multi-channel environment, may lead to customers' decline, and it may ultimately lead to a decline in competitiveness and profitability of distribution companies [1, 3, 8].

In this way, most studies argue that although consumer' rooming behaviors weaken profitability of offline retailers, resulting in declining of offline stores, controlling consumer' rooming behaviors is not an easy matter for offline retailers and distributors [8, $3,10,13]$. The point is that the market is not acting as expected. Moreover, it is not possible to control or let consumers do or not. Sevitt, D. and A. Samuel (2013) argue that consumer's showrooming behavior is an inevitable phenomenon in markets, and the argument that showrooming behavior leads to lower revenues for offline retailers is exaggerated [3, 22]. In addition, their survey in the United States and Britain for showrooming found that $16 \%$ of surveyees are more likely to buy through reverseshowrooming rather than showrooming. In general, the tendency of consumer's rooming behavior in Korea is often indicated to offline to online, while the direction of consumer's rooming behavior in the US or Europe often indicates to online to offline [8]. In other words, consumers make rooming behavior through various smart devices, but the final purchase spot differs depending on the orientation value of consumers and the individual characteristics $[8,16]$.

In this study, however, I try to overcome the limitations of these simple comparisons of the groups of one with showrooming behaviors and the other with reverse-showrooming behaviors, which is separated far from the real marketing circumstances [17, 18, 24]. I would like to present a new viewpoint on understanding and evaluating consumer behavior, commonly referred to "rooming", based on the understanding of what shopping value they really want from the standpoint of consumers. Also, as with all consumer behaviors, social, cultural and individual factors can influence consumer responses and behaviors, and these factors may differ in each country. Therefore, this study compares the differences of rooming behavior depending on the consumers' nationality and suggests implications for distributors and marketers.

\section{Theoretical Background and Hypotheses Development}

\subsection{Shopping Value and Rooming Behavior}

Shopping value is a belief in the final situation that a consumer can perceive or achieve in the buying process. That is, the purpose of shopping value through rooming behavior is 
to acquire optimal shopping value that the consumers can obtain using smart device. According to consumer behaviors in previous studies, value is an antecedent of behavior, and explicit and fully conceptualized value is a criterion for consumer choice, preference, and judgment. Therefore, it can be declared that the value of the consumer is influenced by the buying behavior of the product or service $[4,5,7,25]$.

Shopping value is classified into two types related to shopping behavior, namely shopping value related to work and shopping value associated with fun. The former is a utilitarian value derived from product be designed function, the latter is the hedonic value associated with the response to fun and pleasure $[5,7,25,26]$. Consumers buy products online, but they also like the fun provided in the process of browsing information and web-surfing. In other words, the ultimate goal that consumers seek for is not just simply buying, but enjoyment and experience that comes from rooming behavior. This rooming behavior of consumers seems to have a negative effect on the distribution company's sales at a glance, but ultimately it allows consumers to provide a good experience, convenience and merits in the process of rooming behavior, which is eventually positive effect for loyalty to the distribution company. In particular, unlike the traditional commerce transaction, the shopping value perceived by consumers in the commercial transaction using smart devices differs in the information search process and the purchase decision process [15, 25, 27].

The shopping values on the online oriented by consumers who using smart devices are the value of enjoyment, fun, pleasure value, information value is related to explanation of product search or property, utility value is related with product function, innovation value is associated with innovation, self-identification value is related to self-expression, image oriented value $[13,14,23,26]$.

\subsection{Smart Device Familiarity, Nationality, Consumer Attitude and Behavior on Rooming Behavior}

The greater the perceived shopping value at the point of contact with the buyer, the more the familiarity with the smart devices based on IT technology environment such as smart phone has a positive effect on the rooming behavior. Consumers who are frequently showrooming or morooming can carry out across multi-channels before buying a particular product, and their rooming behavior affects other consumers' purchasing behavior on the online. In other words, consumers who are familiar with rooming behavior have a greater influence on attitudes and behaviors toward purchasing using smart devices. In addition, the higher the value of the consumers' shopping experience using various channels, the more positive the preference, the familiarity and the satisfaction with the rooming behavior [13, 20, 23, 24, 27].

Behavioral intentions influence individual behavior and it is possible to measure the behavioral intentions of the individual in order to investigate the specific behavior of the consumer. The behavioral intention in this study is the purchase intention to purchase the product using the various buying channels based on the information technology environment. The purchase intention represents the end intention of the consumer who intends to purchase a specific product in the future, and is an indicator for determining whether or not he intends to purchase the product in the future. Meanwhile, the previous studies warn that with the technological advancement, the reduction in sales of offline retailers brought by showrooming or morooming could worsen the profitability of the company. However, recent studies have suggested that such a phenomenon is only a short-term appraisal, and that in the long term, differentiated strategies using multichannels may be more effective. In addition, consumers' rooming behavior differs from product search and purchase provided by traditional commerce transaction. Therefore, the value of consumers who make rooming behavior may vary according to nationality and individual characteristics $[21,24,26]$. 


\subsection{Hypotheses Development}

The oriented value of consumers is the motivation and influence factor of attitude and purchasing behavior $[1,2,14,25]$. The hedonic shopping value positively affects the morooming attitude and behavior, and the higher the functional value of the smartphone, the higher the satisfaction and loyalty. In addition, innovative shopping value and selfimage consistency have a positive effect on familiarity with smart devices, which may have a positive effect on attitude and purchase intention. Based on the results of previous studies, the research hypotheses are suggested as follows $[1,2,7,14,21,24,26]$.

H1: There will be positive influence on shopping value and smart device familiarity.

H1-1: There will be a positive influence on the shopping value of environment and protection orientation and smart device familiarity.

H1-2: There is a positive influence on hedonic shopping value and smart device familiarity.

H1-3: There will be a positive influence on utilitarian shopping value and smart device familiarity.

H1-4: There will be a positive influence on the innovative shopping value and smart device familiarity.

H1-5: There is a positive influence on the self-expressive shopping value and smart device familiarity.

$\mathrm{H} 2$ : There will be positive influence on smart device familiarity and attitude.

H3: There will be positive influence on smart attitude and purchase intention.

When a consumer buys a specific product, the consumer tries to find information about the product. In the past, if the method of information search relied heavily on the information provided by word of mouth or the seller, Recent a technical environment for consumers to directly search for information about the product was created. As a result, consumers' behaviors that appear are rooming behaviors, and rooming behaviors that are actively engaged by consumers. Therefore, there may be differences in the value of individual characteristics and familiarity with smart devices. Based on these previous research results, the following hypotheses are suggested [7, 8, 11, 22, 27].

H4: Consumer shopping value will be different according to nationality.

H5: Consumer shopping value will be different according to familiarity.

\section{Research Methodology}

\subsection{Data Collection and Respondents' Characteristics}

To collect this research data, pilot test was conducted on 30 college students who experienced morooming and showrooming on the online and some items were adjusted. In order to select respondents, convenience sampling of respondents who had experience of rooming behavior in each country was conducted, and questionnaires were constructed in each country. After showing questionnaires to graduate students of Chinese nationality and graduate students of French nationality, they went through the process of refining the items to improve their understanding in the language. In addition, the questionnaire was fully explained to those who said that they did not understand the meaning of the question in the process of collecting the questionnaire. The survey period was from October 4 , 2017 to January 13, 2018.

A total of 230 questionnaires were collected. After statistical screening, 219 questionnaires were used for the final analysis. In terms of the demographic characteristics of respondents, there were 121(55.2\%) males and 98(44.8\%) females. Looking at the occupations, $106(48.4 \%)$ students were the most, followed by $57(26.2 \%)$ 
workers. The age of those in their 20's was 88 (40.2\%), followed by 30's was $60(27.4 \%)$ and 40's was 44(20.1\%). The nationality was 135 in Korea, 53 in China, and 31 in France. The respondents' most frequent channels for searching products with rooming behavior were the respondents with smartphones $72.0 \%>\mathrm{PC} 58.3 \%>$ offline stores $40.5 \%$, and the channels that purchase the most with rooming behavior were also measured as duplicate responses, and smartphones $40 \%>$ offline stores $29.6 \%>$ PC $21.3 \%$. In addition, the most frequently searched products were clothing and travel services $47.1 \%$, and the most purchasing items were clothing $33.7 \%$, household goods $26.5 \%$ and household appliances $15 \%$. According to the measured characteristics of the respondents, the students and the workers are the most occupied, the ages are in the $20 \mathrm{~s}$ and $30 \mathrm{~s}$, the products that are searching by the rooming behavior are different from the products that are actually purchased.

\subsection{Measures}

In this study, based on the theoretical background, research hypotheses are derived to analyze the causality and influence of consumer's shopping value on the rooming behavior, and operational definitions for each concept are set as shown in Table 1.

Table1. The Operational Definitions of Measurement Items

\begin{tabular}{|c|l|r|}
\hline Constructs & \multicolumn{1}{|c|}{ Measurement } & Researchers \\
\hline Shopping Value & $\begin{array}{l}\text { The degree of value to be considered or to be } \\
\text { oriented, when searching for or purchasing a } \\
\text { product(safety, environmental protection, utilitarian, } \\
\text { hedonic, entertainment factor, psychological } \\
\text { stability, innovation, ease of use, ease of use, self- } \\
\text { image expression, etc). }\end{array}$ & [25],[26] \\
\hline Familiarity & $\begin{array}{l}\text { The degree of proficiency, usage experience and } \\
\text { cross channels researching with using smart devices } \\
\text { that can increase rooming behavior. }\end{array}$ & [7], [24],[25] \\
\hline Attitude & $\begin{array}{l}\text { The degree of belief, recognition, and judgment on } \\
\text { rooming behavior (show rooming, morooming, web } \\
\text { rooming, etc.) }\end{array}$ & [1],[2],[9],[24] \\
\hline $\begin{array}{l}\text { Purchase } \\
\text { Intention }\end{array}$ & $\begin{array}{l}\text { The degree of recommendation, purchasing, and } \\
\text { revisit intention through rooming behavior }\end{array}$ & [9],[14] \\
\hline
\end{tabular}

\section{Results of Analysis}

\subsection{Test of Reliability and Validity}

We conducted an exploratory factor analysis to derive the main dimension of shopping value of consumers who experienced rooming behavior. Bartlett test was used to examine the correlation between variables before exploratory factor analysis (KMO measure $=.813$, approximate chi-square $=923.239, \mathrm{df}=91, \mathrm{p}=0.000)$ [6]. And the validity of the factor analysis was obtained. As a result of exploratory factor analysis, five shopping factors were extracted with factor of eigen values 1.0 or more. Based on the characteristics of the questionnaire and the previous studies, five factors were named as environmental and protection oriented shopping value, hedonic shopping value, utilitarian shopping value, innovative shopping value, and self - expressive shopping value. We also used Cronbach's $\alpha$ coefficient to verify the reliability of the items used in this study. As shown in Table 2, Cronbach's $\alpha$ value, which indicates reliability, showed a reliability value of 0.7 or more for all 5 factors [6], [12]. 
Table 2. The Results of Exploratory Factor Analysis on Shopping Value

\begin{tabular}{|c|c|c|c|c|c|c|c|}
\hline \multirow[b]{2}{*}{ Items } & \multirow[b]{2}{*}{$\begin{array}{c}\text { Commu- } \\
\text { nality }\end{array}$} & \multicolumn{5}{|c|}{ Factor Name } & \multirow[b]{2}{*}{ Cronbach's $\alpha$} \\
\hline & & $\begin{array}{l}\text { Factor1 } \\
\text { (Env. and } \\
\text { Pro.) }\end{array}$ & $\begin{array}{c}\text { Factor2 } \\
\text { (Hedonic) }\end{array}$ & $\begin{array}{c}\text { Factor3 } \\
\text { (Utili- } \\
\text { tarian) }\end{array}$ & $\begin{array}{c}\text { Factor4 } \\
\text { (Inno- } \\
\text { vative) }\end{array}$ & $\begin{array}{c}\text { Factor5 } \\
\text { (Self- } \\
\text { expressive) }\end{array}$ & \\
\hline cv7 & .730 & .847 & & & & & \\
\hline $\operatorname{cv} 6$ & .642 & .789 & & & & & \\
\hline $\operatorname{cv} 8$ & .598 & .732 & & & & & .194 \\
\hline $\operatorname{cv} 5$ & .639 & .712 & & & & & \\
\hline cv11 & .774 & & .850 & & & & \\
\hline $\operatorname{cv} 10$ & .755 & & .841 & & & & .786 \\
\hline cv12 & .661 & & .740 & & & & \\
\hline $\mathrm{cv} 2$ & .649 & & & .795 & & & \\
\hline cv4 & .654 & & & .769 & & & .710 \\
\hline $\mathrm{cv} 1$ & .637 & & & .763 & & & \\
\hline cv13 & .830 & & & & .896 & & \\
\hline cv14 & .800 & & & & .854 & & .811 \\
\hline cv17 & .764 & & & & & .853 & \\
\hline cv16 & .674 & & & & & .774 & .698 \\
\hline \multicolumn{2}{|c|}{ Eigen value } & 2.495 & 2.115 & 1.944 & 1.812 & 1.491 & \\
\hline \multicolumn{2}{|c|}{ Cumulative $\%$} & 17.821 & 32.930 & 46.815 & 59.757 & 72.694 & \\
\hline
\end{tabular}

In this study, confirmatory factor analysis was conducted to verify the reliability and validity of all the measurement items used in the hypothesis verification. The results of CFA are as in Table 3. AVE value should be at least 0.5 to be reliability. All variables in this study have an AVE value greater than 0.5 (environmental and protection oriented shopping value $=0.794$, hedonic shopping value $=0.718$, utilitarian shopping value $=0.624$, innovative shopping value $=0.725$, and self-expressive shopping value $=0.626$, familiarity $=0.762$, attitude $=0.823$, purchase intention $=0.890$ ). Moreover, the composite reliability was found to exceed the recommendation criterion by exceeding 0.7 . Goodness -of-fit index is acceptable with $\mathrm{CMIN} / \mathrm{DF}=1.565$, GFI=0.943, AGFI=0.809, CFI=0.942, $\mathrm{NFI}=0.900, \mathrm{RMR}=0.041, \mathrm{RMSEA}=0.052$. This goodness-of-fit index enough to explain the causal relationship among research constructs. These results show that reliability and validity are obtained [12]. 
Table 3. Convergent Validity and Reliability

\begin{tabular}{|c|c|c|c|c|c|c|c|c|}
\hline \multicolumn{2}{|c|}{ Construct } & Item & Estimate & $\begin{array}{c}\text { Std. } \\
\text { Estimate }\end{array}$ & S.E. & t-value & CR & AVE \\
\hline \multirow{14}{*}{$\begin{array}{c}\text { Shopping } \\
\text { value }\end{array}$} & \multirow{4}{*}{$\begin{array}{c}\text { Env. and } \\
\text { Pro. }\end{array}$} & CV7 & 1.000 & .588 & - & - & \multirow{4}{*}{0.874} & \multirow{4}{*}{0.794} \\
\hline & & CV6 & 1.279 & .778 & .160 & $8.014 * * *$ & & \\
\hline & & CV8 & 1.030 & .656 & .231 & $4.457 * * *$ & & \\
\hline & & CV5 & 0.890 & .626 & .200 & $4.446^{* * * *}$ & & \\
\hline & \multirow{3}{*}{ Hedonic } & CV12 & 1.000 & .619 & - & - & \multirow{3}{*}{0.826} & \multirow{3}{*}{0.718} \\
\hline & & CV11 & 1.252 & .830 & .145 & $8.608 * * *$ & & \\
\hline & & CV10 & 1.234 & .781 & .145 & $8.505 * * *$ & & \\
\hline & \multirow{3}{*}{ Utilitarian } & CV4 & 1.000 & .613 & - & - & \multirow{3}{*}{0.767} & \multirow{3}{*}{0.624} \\
\hline & & CV2 & 1.172 & .671 & .189 & $6.204 * * *$ & & \\
\hline & & CV1 & 1.354 & .669 & .218 & $6.202 * * *$ & & \\
\hline & \multirow{2}{*}{ Innovative } & CV14 & 1.000 & .976 & - & - & \multirow{2}{*}{0.831} & \multirow{2}{*}{0.725} \\
\hline & & CV13 & 0.734 & .699 & .128 & $5.717 * * *$ & & \\
\hline & \multirow{2}{*}{$\begin{array}{c}\text { Self- } \\
\text { expressive }\end{array}$} & CV17 & 1.000 & .785 & - & - & \multirow{2}{*}{0.706} & \multirow{2}{*}{0.626} \\
\hline & & CV16 & 0.803 & .476 & .196 & $4.098 * * *$ & & \\
\hline \multirow{3}{*}{\multicolumn{2}{|c|}{ Familiarity }} & FA3 & 1.000 & .649 & - & - & \multirow{3}{*}{0.830} & \multirow{3}{*}{0.762} \\
\hline & & FA2 & 1.252 & .840 & .133 & $9.396 * * *$ & & \\
\hline & & FA1 & 0.839 & .663 & .105 & $8.027 * * *$ & & \\
\hline \multirow{4}{*}{\multicolumn{2}{|c|}{ Attitude }} & ATT4 & 1.000 & .882 & - & - & \multirow{4}{*}{0.913} & \multirow{4}{*}{0.823} \\
\hline & & ATT3 & 0.915 & .766 & .067 & $13.732 * * *$ & & \\
\hline & & ATT2 & 0.927 & .819 & .061 & $15.269 * * *$ & & \\
\hline & & ATT1 & 0.939 & .832 & .060 & $15.716 * * *$ & & \\
\hline \multirow{3}{*}{\multicolumn{2}{|c|}{ Purchase Intention }} & PI3 & 1.000 & .946 & - & - & \multirow{3}{*}{0.962} & \multirow{3}{*}{0.890} \\
\hline & & PI1 & 1.047 & .930 & .040 & $26.327 * * *$ & & \\
\hline & & PI2 & 0.924 & .913 & .037 & $24.990 * * *$ & & \\
\hline
\end{tabular}

$* * * \mathrm{P}=0.000, \mathrm{CMIN} / \mathrm{DF}=1.565, \mathrm{GFI}=0.943, \mathrm{AGFI}=0.809, \mathrm{CFI}=0.942, \mathrm{NFI}=0.900, \mathrm{RMR}=0.041, \mathrm{RMSEA}=0.052$

For discriminant validity test, the square root of AVE should be greater than the correlation between every construct. Table 4 shows that all AVEs exceeded the minimum criteria, and all AVEs are higher than squared inter-construct correlations. This result provides evidence of discriminant validity [12]. 
Table 4. Discriminant Validity

\begin{tabular}{|l|c|c|c|c|c|c|c|c|}
\hline \multicolumn{1}{|c|}{ Construct } & $(\mathbf{1})$ & $(\mathbf{2})$ & $\mathbf{( 3 )}$ & $\mathbf{( 4 )}$ & $\mathbf{( 5 )}$ & $\mathbf{( 6 )}$ & (7) & (8) \\
\hline (1) Env. and Pro. & 0.794 & & & & & & & \\
\hline (2) Hedonic & 0.333 & 0.718 & & & & & & \\
\hline (3) Utilitarian & 0.243 & 0.062 & 0.624 & & & & & \\
\hline (4) Innovative & 0.180 & 0.330 & 0.154 & 0.725 & & & & \\
\hline (5) Self-expressive & 0.235 & 0.409 & 0.013 & 0.332 & 0.626 & & & \\
\hline (6) Familiarity & 0.135 & 0.322 & 0.156 & 0.181 & 0.303 & 0.762 & & \\
\hline (7) Attitude & 0.130 & 0.270 & 0.101 & 0.112 & 0.331 & 0.527 & 0.823 & \\
\hline (8) Purchase Intention & 0.087 & 0.178 & 0.087 & 0.141 & 0.287 & 0.589 & 0.627 & 0.890 \\
\hline
\end{tabular}

Notes: The square root of the average variance extracted (AVE) values are presented on the diagonal and Correlations are below diagonal

\subsection{Results of Path Analysis}

Results of path analysis tested indicated acceptable goodness-of-fit-measures $(\mathrm{CMIN} / \mathrm{DF}=1.675, \mathrm{GFI}=0.923, \quad \mathrm{AGFI}=0.877, \mathrm{CFI}=0.959, \mathrm{NFI}=0.918, \quad \mathrm{RMR}=0.049$, RMSEA=0.057). Hedonic, innovative, and self-expressive shopping values have the strongest effect on smart device familiarity, supporting H1-2, H1-4, and H1-5. On the other hand, the path among the environmental and protection oriented shopping value, utilitarian shopping value and smart device familiarity, is not significant rejecting H1-1, H1-3. And smart device familiarity has a significant positive effect on attitude supporting $\mathrm{H} 2$. Attitude has a significant positive effect on purchase intention supporting $\mathrm{H} 3$ as in the Table 5.

Table 5. Results of Path Analysis

\begin{tabular}{|c|c|l|l|l|l|l|l|c|}
\hline \multicolumn{3}{|c}{ Hypotheses } & Estimate & S.E. & C.R. & p-value & Result \\
\hline H1-1 & $\begin{array}{c}\text { Environmental } \\
\text { and Protection }\end{array}$ & $\rightarrow$ & Familiarity & -0.037 & 0.162 & -0.572 & .100 & Rejected \\
\hline H1-2 & Hedonic & $\rightarrow$ & Familiarity & 0.292 & 0.306 & 2.545 & $* *$ & Accepted \\
\hline H1-3 & Utilitarian & $\rightarrow$ & Familiarity & -0.126 & 0.424 & -1.277 & .170 & Rejected \\
\hline H1-4 & Innovative & $\rightarrow$ & Familiarity & 0.401 & 0.386 & 2.931 & $* * *$ & Accepted \\
\hline H1-5 & Self-expressive & $\rightarrow$ & Familiarity & 0.510 & 0.097 & 3.921 & $* * *$ & Accepted \\
\hline H2 & Familiarity & $\rightarrow$ & Attitude & 0.650 & 0.072 & 5.666 & $* * *$ & Accepted \\
\hline H3 & Attitude & $\rightarrow$ & $\begin{array}{c}\text { Purchase } \\
\text { Intention }\end{array}$ & 0.843 & 0.057 & 14.793 & $* * *$ & Accepted \\
\hline
\end{tabular}

$\mathrm{CMIN} / \mathrm{DF}=1.675, \mathrm{GFI}=0.923, \mathrm{AGFI}=0.877, \mathrm{CFI}=0.959, \mathrm{NFI}=0.918, \mathrm{RMR}=0.049, \mathrm{RMSEA}=0.057,{ }^{* *} \mathrm{p}<0.05$, $* * * \mathrm{p}<0.01$ 


\subsection{Results of Mean Analysis by Group}

As shown in Table 6, hedonic shopping value, utilitarian shopping value, innovative shopping value, and self-expressive shopping value, excepting environment and protection-oriented shopping value, show differences between Korean, Chinese and French consumer groups. Therefore, hypothesis H4 is partially supported.

Table 6. Difference in Shopping Value of Rooming Behavior by Nationality

\begin{tabular}{|c|c|c|c|c|c|}
\hline Shopping Value & Nationality & $\mathbf{N}$ & Mean & S. D. & F-value \\
\hline \multirow{3}{*}{$\begin{array}{c}\text { Environmental } \\
\text { And Protection } \\
\text { orientation }\end{array}$} & Korea & 135 & 3.4685 & .80079 & \multirow{3}{*}{0.174} \\
\hline & China & 53 & 3.3988 & .82466 & \\
\hline & France & 31 & 3.5000 & .67082 & \\
\hline \multirow{3}{*}{ Hedonic orientation } & Korea & 135 & 3.8457 & .85539 & \multirow{3}{*}{$6.463 * * *$} \\
\hline & China & 53 & 3.2540 & .67398 & \\
\hline & France & 31 & 3.7742 & .70652 & \\
\hline \multirow{3}{*}{ Utilitarian orientation } & Korea & 135 & 4.0321 & .66152 & \multirow{3}{*}{$3.221 * *$} \\
\hline & China & 53 & 3.7619 & .64722 & \\
\hline & France & 31 & 4.0523 & .57962 & \\
\hline \multirow{3}{*}{ Innovative orientation } & Korea & 135 & 3.9111 & .89540 & \multirow{3}{*}{$2.993 * *$} \\
\hline & China & 53 & 3.7357 & .81445 & \\
\hline & France & 31 & 3.5323 & .83602 & \\
\hline \multirow{3}{*}{$\begin{array}{l}\text { Self-expressive } \\
\text { orientation }\end{array}$} & Korea & 135 & 3.8111 & .87645 & \multirow{3}{*}{$3.290 * *$} \\
\hline & China & 53 & 3.4167 & .88976 & \\
\hline & France & 31 & 3.6935 & .82338 & \\
\hline
\end{tabular}

$* * \mathrm{p}<0.05, * * * \mathrm{p}<0.01$

Lastly, as shown in Table 7, hedonic shopping value, innovative shopping value, and self-expressive shopping value, excepting utilitarian shopping value and environment \& protection-oriented shopping value, show differences between high and low familiarity consumer groups. Hypothesis H5 is partially accepted.

Table 7. Difference in Shopping Value of Rooming Behavior by Familiarity

\begin{tabular}{|c|c|c|c|c|c|}
\hline Shopping Value & $\begin{array}{c}\text { Familiarity } \\
\text { Group }\end{array}$ & $\mathbf{N}$ & Mean & S. D. & F-value \\
\hline \multirow{2}{*}{$\begin{array}{c}\text { Environmental } \\
\text { and Protection orientation }\end{array}$} & High & 103 & 3.3203 & .81130 & \multirow{2}{*}{1.184} \\
\hline & Low & 116 & 3.4844 & .77972 & \\
\hline \multirow{2}{*}{ Hedonic orientation } & High & 103 & 3.9479 & .75780 & \multirow{2}{*}{$5.040 * *$} \\
\hline & Low & 116 & 3.5966 & .82394 & \\
\hline \multirow{2}{*}{$\begin{array}{l}\text { Utilitarian } \\
\text { orientation }\end{array}$} & High & 103 & 3.8646 & .60381 & \multirow{2}{*}{1.132} \\
\hline & Low & 116 & 3.9981 & .66141 & \\
\hline \multirow{2}{*}{ Innovative orientation } & High & 103 & 4.1406 & .84466 & \multirow{2}{*}{$9.310^{* * *}$} \\
\hline & Low & 116 & 3.6364 & .86264 & \\
\hline \multirow{2}{*}{$\begin{array}{l}\text { Self-expressive } \\
\text { orientation }\end{array}$} & High & 103 & 3.9844 & .96290 & \multirow{2}{*}{$3.907 * *$} \\
\hline & Low & 116 & 3.5648 & .85931 & \\
\hline
\end{tabular}

$* * \mathrm{p}<0.05, * * * \mathrm{p}<0.01$ 


\section{Conclusions and Discussion}

The purpose of this study is to understand the rooming behaviors of global consumers based on their shopping values. In order to identify the purpose of the study, path analysis and group mean analysis were conducted. The results can be summarized as follows.

First, the shopping value of global consumers who are performing rooming behaviors was identified as environment and protection-oriented shopping value, hedonic shopping value, utilitarian shopping value, innovative shopping value, and self-expressive shopping value. Hedonic shopping value, utilitarian shopping value, and innovative shopping value that is common in consumers who perform morooming or showrooming behavior. In addition, the value of self-expressive shopping in this study can be seen as unique value as the number of younger generation using multi-channel increases.

Second, hedonic value, innovative value, and self-expressive value were the shopping value that positively affects the familiarity of smart device. This means that the global consumers who have a diverse range of channels have a high desire for fun, pleasure, and self-disclosure. That is, it increases rooming behavior and increases the use of smart devices and increases familiarity.

Third, environment and protection oriented shopping values and utilitarian shopping values did not affect the familiarity of smart devices. In other words, the consumers of rooming behavior prefer experience through rooming activities rather than immediate purchase or functional aspects of a particular product itself, and there may be a temporal discrepancy between the time of information searching and the time of purchase. Therefore, young global consumers need to manage the entire process from information search to purchase, rather than management at the point of purchase. In other words, it means to focus on relationship marketing which can enhance experience.

Fourth, consumers who execute rooming act voluntarily and actively participate in information search and purchase process. Therefore, there may be differences in behavior depending on consumer-oriented values and individual characteristics. As a result of analyzing the difference of shopping value by nationality, the hedonic, utilitarian, innovative and self-expressive shopping values except for environment and protection oriented shopping values showed differences between Korea, China and France consumer groups.

Fifth, there was a difference in hedonic, innovative, and self-expressive shopping value perception between high and low level smart device consumers. This research suggests that even rooming behavior of consumers need differentiated marketing approaches depending on their experience and familiarity with smart devices. These findings can help managers establish differentiating strategies for the growing number of cross shoppers and Omni-shoppers.

Based on the results of the study, this study suggests practical implications as follows. First, perceived shopping value showed differences among groups according to familiarity of smart device of which shows the same result as the path analysis result. In other words, consumers using smart devices for rooming behavior, regardless of their nationality, perceive hedonic value, innovative value, self-expressive value highly than environmental and protection value and utilitarian values, which emphasize experience and relationship. Based on the results, unlike previous researches that retailer's sales may be negatively affected by consumers' increasing roaming behavior, whether online or offline, the result of this study suggests that companies' providing with differentiated technology environment and experience that enables consumers to enjoy and experience rooming can enhance the performance of the company. In addition, hedonic value, utilitarian value, innovative value, and self-expressive value except for environmental and protection value differ according to the nationality of global consumers. In particular, for French consumers with rooming behavior, utilitarian value and self-expressive value are highly pursued. Moreover, innovative value, hedonic value, and self-expressive value turned out 
to be highly pursued for Korean consumers, while innovative value is highly pursued for consumers in China. This suggests that differentiated roaming action strategies are needed for each country. These findings suggest that differentiated rooming behavior strategies are needed to be taken for each country targeting the rooming consumers. For French companies, a strategy of focusing on the reverse-showrooming behavior will be effective, emphasizing utilitarian value and self-expression value. On the other hand, Korean companies should use morooming and pseudo-showrooming strategies that can lead to corporate achievement focusing on consumers' pleasure and novelty, while Chinese companies need an innovative distribution channel strategy that can be differentiated for Chinese consumers in showrooming and morooming.

\section{References}

[1] J. Cha, "Exploring the internet as a unique shopping channel to sell both real and virtual items: a comparison of factors affecting purchase intention and consumer characteristics", Journal of Electronic Commerce, vol. 12, no. 2, (2011), pp. 115-132.

[2] P. Chatterjee, "Multiple-channel and cross-channel shopping behavior: role of consumer shopping orientations", Marketing Intelligence \& Planning, vol. 28, no. 1, (2010), pp. 9-24.

[3] H. C. Chiu, Y. C. Hsieh, J. Roan, K. J. Tseng and J. K. Hsieh, "The challenge for multichannel services: Cross-channel free-riding behavior", Electronic Commerce Research and Applications, vol. 10, no. 2, (2011), pp. 268-277.

[4] J.-Y. Choi, "Consumer Multichannel Choice Behavior in the Information Search and Purchashing Stages", Journal of Consumer Studies, vol. 15, no. 4, (2004), pp. 103-120.

[5] U. M. Dholakia, B. E. Kahn, R. Reeves, A. Rindfleischd, D. Stewart and E. Taylor, "Consumer Behavior in a Multichannel, Multimedia Retailing Environment", Journal of Interactive Marketing, vol. 24, no. 2, (2004), pp. 86-95.

[6] C. Fornell and D. F. Larcker, "Structural equation Models with unobservable variables and measurement error: Algebra and statistics", Journal of Marketing Research, vol. 18, no. 3, (1981), pp. 382-388.

[7] D. Gefen, "E-commerce: The Role of Familiarity and Trust", Omega, vol. 28, no. 6, (2000), pp. 725-737.

[8] Z. Jane Gu and G. Kumar Tayi, "Consumer Pseudo-Showrooming and Omni-Channel Placement Strategies”, MIS Quarterly, vol. 41, no. 2, (2017), pp. 583-606.

[9] K. O. Ha, J. H. Lee and S. H. Hwang, "A Study on Consumer's Shopping Channel Choice according to Consumer Purchase Characteristics", Journal of Distribution Research, vol. 20, no. 4, (2015), pp. 177199.

[10] S. Heitz-Spahn, "Cross-Channel Free-Riding Consumer Behavior in a Multichannel Environment: An Investigation of Shopping Motives", Socio demographics and Product Categories, Journal of Retailing and Consumer Services, vol. 20, no. 6, (2013), pp. 570-578.

[11] Internet Retailer, Top 500 guide, Chicago, 1L: Vertical Web Media LLC, (2013).

[12] J. F. Hair, R. L. T. Anderson and W. C. Black, "NY: Macmillam Publishing Company", Multivariate Data Analysis with Reading. $6^{\text {th }}$ ed. (2006).

[13] S. M. Jun, "The Determinants of Switching on Off-Line Channels for Consumers", The Journal of Digital Policy \& Management, vol. 11, no. 12, (2013), pp. 245-256.

[14] E. Kim and M. C. Park, "Antecedents of Cross-Channel Free-Riding Intention: The Moderating Effect of Product Categories Using Push-Pull-Mooring Framework", Proceedings of the Korea Society of Management Information Systems, (2015), pp. 87-97.

[15] J. H. Kim and H. H. Lee, "I Love the Value From Shopping at Mass Merchants! Consequences of Multichannel Shopping Value”, Journal of Marketing Channels, vol. 21, no. 1, (2014), pp. 18-30.

[16] T. H. Kim, J. H. Kim and S. H. Kim, "Investigating Consumer Showrooming Behavior in a Multichannel Environment", The Journal of Internet Electronic Commerce Research, vol. 18, no. 1, (2018), pp. 203225.

[17] U. Konus, P. C. Verhoef and S. A. Neslin, "Multichannel shopper segments and their covariates", Journal of Retailing, vol. 84, no. 4, (2008), pp. 398-413.

[18] J. A. Oh, "An Analysis on the Omni-Channel Strategy of Distribution Enterprise in Domestic and International", Journal of the Korean Institute of Interior Design, vol. 25, no. 5, (2015), pp. 111-120.

[19] H. K. Park, "Showrooming vs Reverse-Showrooming", Excellence Marketing for Customer, vol. 48, no. 10, (2014), pp. 46-52.

[20] A. Rangaswamy and G. H. van Bruggen, "Opportunities and challenges in multichannel marketing: an introduction to the special issue", Journal of Interactive Marketing, vol. 19, no. 2, (2005), pp. 5-11.

[21] S. Rose, M. Clark, P. Samouel and N. Hair, "Online customer experience in retailing: an empirical model of antecedents and outcomes", Journal of Retailing, vol. 88, no. 2, (2012), pp. 308-322.

[22] D. Sevitt and A. Samuel, "How Pinterest Puts People in Stores", Harvard Business Review, vol. 91 no. $7 / 8,(\mathbf{2 0 1 3})$, pp. 26-27. 
[23] P. C. Verhoef, P. K. Kannan and J. Jeffrey Inman, "From Multi-Channel Retailing to Omni-Channel Retailing: Introduction to the Special Issue on Multi-Channel Retailing", Journal of Retailing, vol. 91, no. 2, (2015), pp. 174-181.

[24] M. S. Yeom, "Inconsistency between Information Search and Purchase Channel: Focusing on the Showrooming Phenomenon", Journal of Distribution Science, vol. 13, no. 9, (2015), pp. 81-93.

[25] B. Anckar, P. Walden and T. Jelassi, "Creating Customer Value in Online Grocery Shopping", International Journal of Retail \& Distribution Management, vol. 30, no. 4, (2002), pp. 211-220.

[26] J. M. Carpenter and M. Moore, "Utilitarian and Hedonic Shopping Value in the US Discount sector", Journal of Retailing and Consumer Services, vol. 16, (2009), pp. 68-74.

[27] C. Grönroos and A. Ravald, "The Value Concept \& Relationship Marketing", European Journal of Marketing, vol. 30, no. 2, (1994), pp. 19-33.

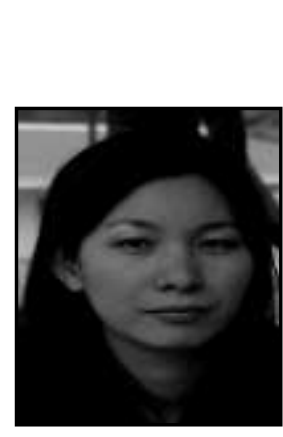

Author

Gwijeong Park, is corresponding author. She is a Lecturer in the Department of Business Administration at Gyeongsang National University, Jinju, South Korea. Her current research interests include channel management, retailing strategy, international marketing, service marketing and consumer behavior. She has published papers in journals such as Journal of Korean Distribution and Management, Journal of Korean Marketing Management Research, The Journal of Internet Electronic Commerce Research. 